\title{
Ablatif Lazerler
}

\section{Ablative Lasers}

\section{Bekir Aybey, Gönül Ergenekon}

Florence Nightingale Hastaneler Grubu, İstanbul, Türkiye

\section{Özet}

Estetik düzenlemeler için geliștirilen cerrahi olmayan lazerler ile cilt yenileme alanı, yeni araștırmalar ve teknik ilerlemelerle gelișimini devam ettirmektedir.1980'lerdeki ilk kullanımlarından bu yana lazerle cilt yenileme endüstrisi ablatif, nonablatif ve fraksiyonel ablatif özellikte çok sayıda cihaz geliștirmiștir.

Ablatif cilt yenileme, yașlanmıș derinin rejuvenasyonu ve çok sayıdaki deri lezyonunun tedavisi için oldukça güçlü bir araçtır. Uygun ellerde kullanıldıklarında, cerrahi ve nonablatif metodların tavsiye edilmediği fotoyașlanma problemlerinin çoğunda etkili ve güvenli bir yöntemdir. Ablatif lazerler, ürettikleri infrare ıșık sayesinde "su" molekülünü hedefleyerek, doku kontraksiyonu ve kollajen üretimine neden olurlar. Illk ablatif lazer sistemleri, belirgin termal hasar olușturduklarından kabul edilemez yüksek oranlarda skarlașma ve uzamıș yara iyileșmesine neden olmușlardır. Yüksek enerjili pulse lazerler ve fraksiyonel lazerler gibi yeni cihazlar, daha az yan etki ve kıssa yara iyileșme süreleri ile belirgin düzelmelere ulașabilme kapasitesine sahiptirler. Ablatif cilt yenileme giderek daha güvenli olmakla beraber, tedavi sonrası skarlașma, pigment düzensizlikleri ve enfeksiyonları engellemek için dikkatli ve uygun hasta seçimi halen çok önemlidir. Hasta tatmini ve klinik sonuçların en üst düzeyde olabilmesi için , ablatif cihazları kullanan klinisyenlerin muhtamel yan etkilerin farkında olmaları gereklidir. (Türkderm 2012; 46 Özel Sayı 1: 36-44)

Anahtar Kelimeler: Ablatif lazerler

\section{Summary}

The field of nonsurgical laser resurfacing for aesthetic enhancement continues to improve with new research and technological advances. Since its beginnings in the 1980s, the laser-resurfacing industry has produced a multitude of devices employing ablative, nonablative, and fractional ablative technologies. Ablative resurfacing is a powerful tool for rejuvenation of the aging face and for the treatment of a wide array of skin lesions. In the proper hands, it is a safe and effective way to treat many of the problems of photodamaged skin that surgery or nonablative methods cannot address. Ablative lasers emit infrared light, which targets water resulting in tissue contraction and collagen formation. The first ablative laser systems created significant thermal damage resulting in unacceptably high rates of scarring and prolonged healing. Newer devices, such as high-energy pulsed lasers and fractional ablative lasers, are capable of achieving significant improvements with fewer side effects and shorter recovery times. While ablative resurfacing has become safer, careful and appropriate patient selection is still important to avoid post-treatment scarring, dyspigmentation, and infections. Clinicians utilizing ablative devices need to be aware of possible side effects in order to maximize results and patient satisfaction. (Turkderm 2012; 46 Suppl 1: 36-44)

Key Words: Ablative lasers

\section{Giriş}

Ablatif cilt yenileme lazerleri çevre dokularda sınırlı bir koagülatif nekrozla birlikte kontrollü bir doku ablasyonu sağlayan lazerlerdir. Ablatif cilt yenileyici lazerlerin fototermal hasar ile epidermis ve dermisin bir kısmını ortadan kaldırarak oluşturdukları doku ablasyonu, gereksede ablate edilmiş doku çevresinde ürettikleri residüel ısı ile kollajenin yeniden yapılanması ve depolanmasını uyardıkları düşünülmektedir. Bu şekildeki bir reepitelizasyon, dermal neokollajenoz ve dermal yeniden yapılanma cildin daha genç görünmesine ve deri yapısının daha da düzelmesine neden olur ${ }^{1-4}$

Yazışma Adresi/Address for Correspondence: Dr. Bekir Aybey, Florence Nightingale Hastaneler Grubu, Istanbul, Türkiye

$$
\text { E-posta: drbekiraybey@hotmail.com }
$$

Türkderm-Deri Hastalıkları ve Frengi Arșivi Dergisi, Galenos Yayınevi tarafından basılmıștır.

Turkderm-Archives of the Turkish Dermatology and Venerology, published by Galenos Publishing. 
Illk ablatif lazerler karbondioksit (CO2) lazerlerdir. CO2 lazer 10600 nm dalga boyunda, elektromagnetik spektrumun orta infrare kısmında görünmez ışın yayar. Bu dalga boyundaki ışın dokunun ana komponenti olan intrasellüler ve ekstrasellüler su tarafından nonselektif olarak emilir. Karbondioksit lazer (CO2); dermatolojik, cerrahi ve oftalmolojik uygulamalar için 1960'lardan beri uzun yıllar geniş kullanım alanı bulmuş gaz lazerlerdendir. Fakat bu dönemlerde "selektif fototermolizis" kavramı henüz gelişmediğinden ilk kullanılan lazerler devamlı dalga (continuous wave) lazer olmuştur3-5. 1983'de "Selektif Fototermoliz" kavramının geliştirilmesiyle6 birlikte pulse (atım) süreleri 250 mikrosaniye ile 1 milisaniye arasında değişecek şekilde "Süperpulse" ve "Ultrapulse" Karbondioksit lazerler geliştirilmiştir. Böylece çevre dokularda oluşabilecek termal hasar, eski devamlı dalgalı (CW) Karbondioksit lazerlerden çok daha az olmaktadır. Bu özelliklere sahip pulse ve skan edilebilen CO2 lazerler 1995'den beri geniş bir şekilde cilt yenileme işlemlerinde kullanılmaya başlanmışlardır. 1996 yılında CO2 lazerler, cilt yenileme (resurfacing) amacıyla FDA onayı almıştır ve cilt yenileme için halen "altın standart" özelliğini taşımaya devam etmektedir3-5,7. Mükemmel sonuçlarına rağmen $\mathrm{CO} 2$ lazerler ile cilt yenileme belirgin riskler taşımaktadır. Postoperatif sürecin her hasta tarafından tolere edilememesi, uzamış postoperatif eritem, dispigmentasyon ve kalıcı skar riskleri CO2 lazer ile cilt yenileme işlemini çoğu zaman belirli, şeçilmiş hasta gruplarına sınırlı hale getirmektedir3-5,7.

Cilt yenileme işleminde CO2 lazerlerin bu zorluklarını minimalize etmek ve kısa yara iyileşme süreci içinde daha yüzeyel ablasyonlar sağlamak amacıyla diğer bir cilt yenileme lazer sistemi olan 2940 nm Erbium:ytrium-aluminumgarnet (Er:YAG) lazer sistemleri geliştirilmiştir. Kısa-atım süreli Er:YAG lazer ilk olarak 1996 yılında cilt yenileme amacıyla FDA onayı almıştır3-5,8. Kısaatımlı Er:YAG lazer, erbium elementi ile desteklenmiş flashlamp-kaynaklı kristal lazer sistemidir.2940 nm dalgaboyunda elektromagnetik spektrumum orta-infrare bölümü içinde ışın yayar, ki bu dalgaboyunda Er:YAG lazer'in su absorbsiyon kapasitesi, CO2 lazerden 12-18 kat daha fazladır-5,8. Epidermisin \%90'ı su intiva ettiğinden Er:YAG lazer enerjisinin çoğu su intiva eden yüzeyel dokularda absorbe edilir. Bunun sonucu kuvvetli bir ablasyondur, çevre dokularda ısınma ve kollajen kontraksiyonu daha zayıftır. CO2 lazerlere kıyasla çok etkili ablasyon fakat sınırlı bir koagülatif nekroz oluşturduğundan, Er: YAG lazer'in doku etkisi fototermal olmaktan ziyade daha çok fotomekaniktir. CO2 lazer ise daha çok fototermal etkilidir. Er:YAG lazer'in yüzeyel ablasyon ve dar termal hasar zonu oluşturma etkisi ince bir dokunun ablasyonunu sağlar ,daha az kollajen kontraksiyonuna ve ayrıca yetersiz bir hemostaza neden olur.Buda işlem sırasında ortamın kanlanmasını ve görüş alnının kısıtlanmasına neden olabilir3-5,8.

Kısa-atımlı Er:YAG lazerlerin bu eksik taraflarını kompanse edebilecek "modüle Er:YAG lazer sistemleri" geliştirilmiştir3,5,9. Şu an için 3 modüle sistem mevcuttur: 1) Er:YAG lazer ve $\mathrm{CO} 2$ hibrid lazer sistemlerinin kombinasyonu (Derma-K, ESC Medical systems, NeedhamMA) 2) Dualmode, ablasyon/ koagülasyon, pulse Er:YAG lazer (Contour, Sciton, Palo Alto,CA) 3) Variable-pulsed (değişken-atımlı) Er:YAG lazer (CO3, Cynosure, Chelmsford, MA. CO2 lazer için karakteristik olan kollajen kontraksiyon kabiliyeti bu lazerlerle de görülebilir düzeydedir9. Her 3 lazer sisemi de iyi etkileri, gelişmiş hemostaz yetenekleri ve kontrollü termal hasar derinlikleri sağlamaları nedeniyle CO2 lazere iyi bir alternatif olmuşlardır ${ }^{9}$.

Son dönemlerde karbonioksit cilt yenileme lazerlerinin etkilerine yakın ama yan etki ve iş-güç kaybı daha minimal cilt yenileme lazer incelemeleri çerçevesinde geliştirilen lazerlerden biri de $2790 \mathrm{~nm}$ dalgaboyunda Er:Yttrium Scandium Gallium Garnet (YSGG) Lazer'dir.10,11 Er :YSGG Lazer; $2790 \mathrm{~nm}$ dalgaboyunda, su absorbsiyon katsayısı CO2 lazerden fazla, Er:YAG lazerden azdır.Bu değerin CO2 lazerden daha hasas kontrollü bir derinlik sağladığı ama Er: YAG lazerden daha fazla rezidüel termal hasara neden olacağı düşünümektedir.Epidermisin bir bölümü kontrollü miktarda buharlaştırma ile güvenli bir şekilde çıkarılır.Bu proseste 10-30 mikron kalınlığında epidermis buharlaştıııır10,11.

\section{Hasta Seçimi ve Endikasyonları}

Sağlıklı her yaş insana lazer ile cilt yenileme uygulanabilir. Lazer ile cilt yenileme tekniği için en ideal hasta grubu; açık renk cilt tipine sahip (Fitzpatrick deri prototipi I veya II) , kabul edilebilir gerçekçi beklentiler içinde olan ve özellikle lazerin etki derinliğine sahip lezyonları olan kişilerdir. Genel olarak epidermis ve dermisi içeren kırışıklık ve fotoyaşlanma tedaviye iyi yanıt verir. Yaşlanma ile seyreden epidermal patolojiler söz konusu olduğunda aktinik keratoz, in-situ skuamöz hücreli karsinom, lentijinler ve seboreik keratozlar epidermal tabakanın bu lazerlerle temizlenmesiyle tedavi edilebilirler. Başarılı bir sonuç için hastaların operasyon öncesi iyi değerlendirilmesi ve işlem hakkında çok iyi eğitilmiş olmaları kesinlikle gereklidir. Lazer ile cilt yenileme yöntemi kabul edilemeyecek skarlaşma, pigment değişiklikleri veya uzamış postoperatif iyileşme periyodu gibi komplikasyonlara neden olabileceğinden uygun hasta seçimi işlemin en can alıc bölümünü teşkil etmektedir. Lazer cinsinin tayini ablate edilecek dokunun yapısıyla ilgilidir. Hafif ve orta derecede ışık hasarına uğramış deriye sahip (Glogau tip I veya II) hastalar, hafifçe atrofik yüz skarları, diskromiler ve ışık hasarı ile oluşmuş kırışıkıklar Er:YAG lazer ile cilt yenileme için ideal endikasyonlardır. Derince atrofik yüz skarları, orta ve şiddetli ışık hasarına uğramış deri (Glogau tip III veya IV), ve ışık hasarı ile oluşmuş şiddetli yüz kırısıklıkları daha derin penetrasyona sahip, kollajen kontraksiyonu uyaran ve çok iyi hemostatik kapasiteye sahip CO2 lazere ve Module sistemlere intiyaç gösterirler 1,2,5,12,13

Diğer cerrahi mudahaleler de olduğu gibi, hasta tatmini yönünden en önemli belirleyici faktör hasta beklentileridir. Hasta gerçekçi beklentiler içinde olmalıdır. Lazerin komplikasyonları, postoperatif bakım ve burada karşılaşılabilecek problemler hastaya iyice anlatılmalıdır. Postoperatif iyileşme süresinin uzunluğu ve postoperatif dönemi tolere edebilecek hasta emosyonel kapasitesi, lazer seçimini belirleyen diğer faktörlerdir. Bu zorlu periyodu kaldıramayacak kişilerde CO2 lazer yerine Er:YAG lazerin tercih edilmesi daha uygun olabilir. Yine deri tipi III ve yüksek kişilerde postoperatif hiperpigmentasyon oldukça sık görülür ve özellikle CO2 lazer sonrası aylarca devam edeblir. Fakat Er: YAG lazer sonrasında ise genellikle 1 ay içinde geriler. Bu nedenle koyu renk deri tipine (Fitzpatrick fototip III ve üstü) sahip hastalar için Er: YAG lazer kısmen daha iyi bir seçenek olabilir.Topikal renk açı ı kremler veya kimyasal peelinglere yanıt vermeyen refrakter melasma olgularının Er: YAG lazere iyi yanıt verdiği gösterilmiştir. Yine ışık hasarına uğramış boyun ve el sırtı derisinin yenilenmesinde de Er: YAG lazer başarıyla kullanılabilir. Bu bölgelerde CO2 lazer kullanımı oldukça fazla fibroz ve hipertrofik skar riski taşımaktadır. Er: YAG lazerin bir özel endikasyonu da ; konvansyonel CO2 lazer abrazyonundan sonra termal olarak etkilenmiş nekroz dokusunu uzaklaştırmak için (ki bunun yara iyileştirmesini hızlandırdığı ve eritem süresini kıssalttığı düşünülmektedir) kullanılabilmesidir 1,2,5,12,13.

\section{Diğer Endikasyonlar}

Lazer ile cilt yenileme tekniği, fotoyaşlanma dışında birçok tıbbi tabloda da kullanılabilmektedir. Özellikle deprese veya eleve akne skarlarında başarıyla kullanılabilmektedir. İce-pick ve krater tarzı (bound down) akne skarlarında 
ise doku öncelikle punch veya lineer eksizyonlarla alınmalı, punch elevasyon veya puch greftleme uygulanmalı ve bunlardan 6-8 hafta sonra lazer ile cilt yenileme uygulanmalıdır. Krater formundaki varisella skarları, aktinik keilit, aktinik keratozlar, postenflamatuar hiperpigmentasyon ve gözaltı morlukları gibi pigmentasyon bozuklukları cilt canlandırı lazerler ile düzeltilebilirler. Melasmanın yanıtı diğer tedavi seçeneklerinde olduğu gibi değişkendir1,2,5,12,13.

Rinofima, epidermal nevüsler ve siringoma, trikoepitelyoma, milier osteoma, dermatosis papulosa nigra, Hailey Hailey hastalığı ve Darier hastalığının kütanöz bulguları, ksantelasma, adenoma sebaseum, sebase hiperplazi gibi değişik ufak benign oluşumlar rutin olarak konvansyonel CO2 lazerler ile tedavi edilegelmişlerdir. Bu tablolarda cilt canlandırıc yeni CO2 lazerlerin kullanımı yara iyileşme sürecini kıssaltıp, yan etki risklerini azaltabilir. Bazen kombine yaklaşımlar faydalı olabilir1,2,5,12,13.

\section{Kontraendikasyonlar}

Uygun hasta seçimi ve gerçekçi hasta beklentileri başarılı bir lazer cilt yenileme işlemi için oldukça kritik önem taşımaktadır. Fotoyaşlanmanın klinik bulguları mevcut olsa bile; uygun beklenti içinde olmayan hastalar, kelloid oluşumuna yatkın hastalar, uygun postoperatif bakım rejimlerini kaldıramayacak hastalarda lazer ile cilt yenileme tekniği düşünülmemelidir1,2,5,12,13.

Lazerle cilt yenileme sonrası yara iyileşmesi için adneksal yapılar kritik önem taşıdıklarından azalmış sayıda veya kalitesi bozulmuş adneksal yapılara sahip hastalar (skleroderma veya yanık hastaları gibi) da endikasyon zayıftır. İyonize radyasyon ve retinoik asit tedavisi alan hastalarda skar riski fazla olduğundan dikkat edilmelidir. Kütanöz lazer cilt yenilemesi isotretinoin tedavisi tamamlandıktan 6-12 ay sonra yapılabilir. Yüz gerdirme ve blefaroplasti gibi kan dolaşımını etkileyebilecek işlemlerden sonra 3-6 ay beklenmesi önerilir 1,2,5,12,13.

Kişisel veya ailesel vitiligo hikayesi, kişisel skleroderma hikayesi, radyasyon tedavisi, köbnerizasyona eğilimli durumlar (psoriasis gibi), travmaya sekonder skar eya keloid oluşturma eğilimi, hamilelik ve emzirme rölatif kontraendikasyon içindedirler1,2,5,12,13.

\section{Preoperatif Tıbbi Yaklaşım}

Lazer ile cilt yenileme işlemini güvenli kılmak ve hastaya daha fazla konfor sağlamak için lazer öncesi birtakım tıbbi yaklaşım faydalı olabilir. Cilt yenilemeden haftalar öncesinde topikal retinoik asit bileşikleri, hidrokinonlu renk açıcılar veya alfa hidroksi asitler gibi ürünlerin kullanılmasının lazer sonrası iyleşmeyi hızlandırdığı ve postenflamatuar hiperpigmentasyon riskini azalttığı düşünülmektedir5,13. Fakat, lazer öncesi kullanılması gereken tedavi hakkında herkes tarafından kabul görmüş kesin bir protokol yoktur.

Lazerle cilt yenileme işlemi herpes ataklarını stimüle edip ağrı, uzamış postoperatif eritem ve skar gibi komplikasyon risklerini arttırabileceğinden daha önceden herpes enfeksiyonu geçirmiş veya hiç geçirmemiş herkese profilaktik oral antiviral tedavi başlanmalıdır. Oral asiklovirin, günde 3 kez 400 mg veya oral valosiklovirin, günde 2 kez 500 mg işlemden 2 gün önce başlanıp, işlemden sonraki 10 güne kadar devam edilmesi önerilir. Lazerle cilt yenileme sonrası termal olarak hasar sonucu oluşmuş nekrotik, koagüle bir dermis tabakası birkaç gün boyunca devamlı atılacağından ve bu tabaka bakteriler için ideal bir kültür ortamı olabileceğinden profilaktik oral bir antibiyotiğin kullanılması tavsiye edilir. Dicloxacillin, günde 2 kez 500 mg veya penisilin allerjisi olanlarda azitromisin (500 mg ilk dozu takien günde
$250 \mathrm{mg}$ ) veya siprofloksasin (2x500 mg) işlemden 1 gün önce başlayıp, işlemden sonraki 5 gün boyunca devam edecek şekilde kullanılabilir. Bazı hekimler, işlem bölgesinde kandidiyal enfeksiyon riskini önlemek için işlem sırasında tek doz oral flukanazol tavsiye ederler. İşlemden sonraki ilk 72 saatte ortaya çıkan yüz ödemini engellemek için 3-4 günlük kısa bir oral kortikosteroid kürü uygulanabilir13-15.

\section{Anestezi}

Topikal anestezi (operasyondan 1-2 saat önce oklüzyon ile uygulanan EMLA veya lidokain pomadlar) kısmi rahatlama sağlamakla beraber 2'den fazla lazer geçisi yapılacak ise veya geniş lezyonlarda genellikle yeterli olmazlar. Tüm yüzün CO2 lazer cilt yenilemesi için intravenöz sedasyon yapmadan, yüzün lateral alanlarına tümesan anestezi infiltrasyonu ile birlikte sinir blokajları (supraorbital, infraorbital, mental) uygundur. Isslemden 30 dakika önce anksiyolitik verilmesi, lidokain miktarının azaltılmasına katkıda bulunabilir1,2,12,13.

\section{Postoperatif Bakım}

Optimal bir sonuç için postoperatif bakım çok önemlidir. İşlem sonrası kabuklanmanın engellenmesi ve ağrı açısından ilk 48 saat hidrojeller veya bioklüzif membran yara örtülerin uygulanması uygundur. Uzun süreli oklüzyon sekonder bakteriyel veya kandidiyal enfeksiyonlara neden olabilir. Oklüzif yara örtülerinin alınmasından sonra, gün içinde sık sık soğuk ıslak pansumanlar ve arkasından vazelin benzeri saf besleyici kremler uygulanabilir. Reepitelizasyon tipik olarak 6-7 günde gerçekleşmesine rağmen, postoperatif eritem aylarca kalabilir. Dikkatlice seçilmiş ve uyumlu hastalarda etkiler daha yüz güldürücüdür12-15.

\section{Yan Etkiler}

CO2 lazer ile cilt yenileme sonrası kısa-süreli ve uzun-süreli yan etkiler görülebilmektedir. 1-3 ay sürebilen geçici cilt hasasiyeti, peeling ve kızarıklık beklenen reaksiyonlardır. En sık görülen kısa vadeli yan etki \%84'e kadar görülen milia ve akneiform döküntülerdir. Preoperatif retinoid kullanılması bu insidansı azaltabilir. Rekürran Herpes Simpleks virüs enfeksiyon hikayesi bulunan hastarlda, profilaktik valacyclovir dozları ile perioperatif herpes simpleks virus enfeksiyonunu engellenebilir. Postoperatif bakteriyel ve kandidiyal enfeksiyonlar nadiren görülür ve uzamış oklüzif yara örtü kullanımı veya zayıf postoperatif yara bakımıyla ilgili olabiliı1,2,5,12,13.

Sık görülen geçikmiş yan etkiler hiperpigmentasyon ve hipopigmentasyondur. CO2 lazer onrası hiperpigmentasyon insidansı, cilt tiplerine göre değişmekle birlikte \%26-36 arasındadır. Hipopigmentasyon ise \%8-19 arasında görülür. Hipertrofik skar, \%2-3 hastada görülebilir ve intralezyonel streroid veya pulse boya lazer tedavisine yanıt verir. Yüksek enerjili pulse CO2 lazerler ile devamlı-dalga CO2 lazerler arasında yan etki yönünden belirgin faklılık söz konusudur1,2,5,12,13.

2790 nm Erbium:yttrium-scandium-gallium-garnet (Er:YSGG) lazerin riskleri, diğer ablatif ve fraksiyonel ablatif cilt yenileme lazerlerinkilerine benzerlik gösterir. Skar ve pigment kaybına neden olabilen yoğun ısıtma, YSGG lazerde Fraksiyonel CO2 lazerden daha az gibi görünmektedir ve muhtamelen yüksek koagülasyon gücünde kullanıldıklarında Er:YAG lazerdekinden bile azdır11,16.

Deri tip I-III hastalarda, düşük ve yüksek fluenslerde 2790 nm Er: YSGG lazer ile yapılan ablatif tedavilerde de postenflamatuar hiperpigmentasyon bildirilmemiştir10,17-21. Bunakarşın tek seans CO2 lazer ila çok seans 2940 
nm Er:YAG lazeri karşılaştıran çalışmalarda, tip I-II hastalarda \%24-40 PIH saptanmış 22 ve periorbital bölgede perioral bölgeden daha fazla görülmüştür.

\section{CO2 Lazer Cilt Yenileme}

CO2 lazerler ilk kez 1960'larda tanıtılmış ve başlangıçta dokuyu kesme amaçı devamlı-dalga modunda kullanılmıştır. Bu şekilde kullanılmasının avantajı daha kansız bir işlem gerçekleştirmesi ve posoperatif yara iyileşmenin daha kısa olmasıdır. Doku kesme üzerinde etkili olmalarına rağmen, ilk CO2 lazerler çevre dokularda da belirgin termal hasarlar da oluşturmuşlardır, bu da kullanımlarını sınırlamıştır.1990'larda yüksek enerjili, atımlı (pulse) CO2 (HEPCO2) lazerlerin geliştirilmesi tekrar kullanım alanlarını genişletmiştîn ${ }^{12}$.

CO2 lazer $10600 \mathrm{~nm}$ dalgaboyunda uzak infrare spektrumda ışık yayar. Enerji öncelikle intrasellüler su tarafından absorbe edilir ve bunun sonucunda doku hızla ısınır ve dokunun buharlaşmasına neden olur. Yüksek-enerjili kısa-atımlı CO2 lazerler (HEPCO2), skar ve hipopigmentasyon gibi yan etkilerden sorumlu derin termal hasarı minimalize ederek oldukça yüzeyel bir doku buharlaşmasına neden olurlar. Doku kesme amacıyla kullanılan devamlı-dalga modundaki CO' lazerler 400-500 mikronluk bir dokuyu ablate ederlerken; Ultrapulse CO2 lazer (Coherent Laser Corp., Palo Alto, CA) 3 mm başlık ve $450 \mathrm{~mJ}$ enerji ile 1 geçişte 20-30 mikronluk dokuyu, 2 geçişte 50 mikronluk dokuyu ve 3 geçişte 70 mikronluk dokuyu ablate eder. Silktouch ve Surgilase (Sharplan Lasers, Inc., Allendale,NJ) CO2 lazerlerde ise ablasyon derinliği biraz daha fazla olup, 2 geçişte 80-100 mikron ve 3 geçişte 150 mikron derinliktedir. Ablasyon zonunun altındaki termal hasar, doku kontraksiyonu ve kollajen yeniden yapılanması uyarır ${ }^{12}$.

\section{CO2 Lazerin Kozmetik Uygulamaları}

\section{Fotoyaşlanma ve Kırışıklıklar}

Yüksek enerjili pulse CO2 lazerin (HEPCO2) en önemli kullanım alanlarından biri düzensiz renk değişiklikleri ve kırışıklıklarla seyreden fotoyaşlanmış cildin yenilenmesidir. Daha önce kullanılan dermabrazyon ve peelinglere göre avantajı termal hasarın kontrol edilebilmesi ve ablasyon derinliğinin hasas ayarlanabilmesidir1,2,5,12.

Yüksek enerjili pulse CO2 lazer, kırışıklık tedavisinde ve cilt yenilemede halen alıı standart olarak yerini korumaktadır.CO2 lazer için ideal durumlar; orta derinlikteki kırışıklıklar ve Tip I ila Tip II fotohasardır. Bu tekniğin etkinliği ve güvenirliliğini inceleyen çok sayıda çalışma yapıımıştır. Illk çalışmalardan birinde 23 alın, glabella, periorbital veya perioral kırışıklıkları olan 259 hasytaya 1-5 geçişli (500 mJ,5-7 W) Ultrapulse CO2 lazer uygulanmış ve tüm alanlarda ortalama \%90 iyileşme saptanmış. Perioral bölge en iyi sonucu (\%93) gösterirken, glabella gibi dinamik kırışıklık bölgeleri daha az yanıt $(\% 86,8)$ vermiş. Diğer bir çalışmada24; kırışıklık derinliğinde \%76-92 azalma saptanmış ve 1 yıl içinde bu değerler \%56-76 'ya düşmüş ve postoperatif ödemin geç gerilemesine bağlanmış. Sharplan Silktouch (Sharplan Lasers,Inc) ile perioral kırışıklıkların derinliğinde \%91 azalma bildirilmiş ve postoperatif 2 yıl sonra bu değer $\% 87$ civarında imiş25. Manuskiatti ve arkadaşları26, cilt yenileyici lazer uygulanan104 hastayı retrospektif olarak incelemişler. Hasta memnuniyeti genel olarak iyi olmakla birlikte perioral cilt yenileme hastalarında memnuniyet daha yüksekmiş. 2 yıllık takip sonrası perioral bölge kırışıklıklarında ortalama \%38 iyileşme saptanırken, periorbital bölgede $\% 31$ imiş.

\section{Akne ve Cerrahi Skarlar}

Geçmişte dermabrazyon yöntemi akne skar tedavisinde en sık kullanılan yöntemdi. Bu teknik oldukça operatöre bağlı bir yöntemdi ve işlem sırasında cevreye dağılan kan elemanlarından dolayı hekim için enfeksiyon riski taşımaktaydı. CO2 lazer ile cilt yenilemenin dermabrazyona bir üstünlüğü saptanamamasına rağmen, pulse CO2 lazerlerin kullanımı akne skar tedavisini oldukça değiştirmiştir. CO2 lazer, skar revizyonu ve cilt yenileme için daha kontrollü bir yaklaşım sunmuştur.CO2 lazer ile cilt yenileme hafif akne skarlarında etkili iken, "ice pick" gibi şiddetli skarlarda, tek başlarına sınırlı etkiye sahiptir.Bu durumda punch graft veya subsizyon gibi ilave tekniklerle kombinasyonu gerekebilmektedir1,2,5,12.

CO2 lazer ile tedaviden 1 ay sonrası akne skarlarında \%69"lara kadar iyileşmeler gözlenmiştir 27 .

İşlemden 18 ay sonrasına kadar klinik etkinin hafif de olsa artarak devam etmesi, dermal yeniden yapılanma ve yeni kollajen oluşumunun devam ettiğini düşündürmektedir.

Nehal ve arkadaşları28; yüzdeki cerrahi skarlarının revizyonunda dermabrazyon ve $\mathrm{CO} 2$ lazerin etkinliğini karşılaştırdılar. 4 hastanın skarlarının yarısına dermabrazyon, diğer yarısına da CO2 lazer uyguladılar. Skarın klinik görünüm ve yapısındaki düzelmede her iki yöntem de etkili iken; CO2 lazer ile tedavi edilen bölümde daha az perioperatif kanama ve postoperatif kabuklanma gözlediler.

\section{CO2 Lazer Tıbbi Uygulamaları}

\section{Aktinik Keratoz Tedavisi}

Melanom dışı deri kanserlerinin tedavisi ve profilaksisi için CO2 lazerler kullanılmış ve değişken sonuçlar bildirilmiştir. Yüz, alın ve saçlı deride yaygın aktinik keratozları olan 25 hasta lazer ile ablatif cilt yenileme sonrası ortalama 39 ay takip edilmiş, bu süre zarfında olguların \%44'ünde rekürrens gözlenmezken, \%56 olguda az sayıda yeni lezyon gözlenmiştir. Rekkürenslerin \%20'si ilk yıl içnde, \%36'sı ise 1 yıldan sonra gözlenmiştir. En sık görülen kısa- ve uzun vadeli yan etkiler; enfeksiyon (\%12), hipopigmentasyon (\%48), hiperpigmentasyon (\%8), akne (\%12), skar oluşumu (\%8), ve deride atrofi ve/veya kolayca morarma (\%20) imiş29. Aktinik keratoz için tüm yüze CO2 lazer uygulanan 31 hastanın 18'inde (\%58) uzun süre lezyonlar tamamen kaybolmuş. Aktinik keratozsuz ortalama süre 27,4 ay imiş30. Teorik olarak, fotohasarlı bir ciltte eğer epidermis tamamen ablate edilirse, alt tabakalarda ışıktan korunmuş folliküllerden tekrar bir epitelizasyon gelişmelidir. Lazer ile cilt yenileme sonrası aktinik keratozlar ve nonmelanoma deri kanserlerinde azalma beklenebilir. Bu şekilde lazerle proflaktik cilt yenileme ile ilgili az sayıda çalışma mevcuttur. Yüz bölgesinde yaygın aktinik keratozları olan 24 hastaya Ultrapulse CO2 ve/veya Er:YAG lazer uygulanması sonrası lezyonlar tamamen temizlenirken, 21 (\%87) olguda en az 1 yıl lezyonlar tekrarlamazken, 24 (\%58.3) olguda 2 yıl içinde yeni lezyon gözlenmemiş. Total olarak aktinik keratoz sayısında \%94 azalma saptanmış. Tüm yüz ablatif lazer tedavisinin uzun süreli Aktinik keratoz proflaksisinde ve aktinik keratoz üzerine skuamöz hücreli karsinom gelişme insidansının azaltılmasında etkili olduğu yorumu yapıımıştı 31 . Hantash ve arkadaşları32 randomize kontrollü bir çalışmada; nonmelanoma deri kanser proflaksisi amacıyla 27 hasta üzerinde topikal 5-fluorouracil, trikloroasetik asit peelingi ve CO2 lazer cilt yenleme yöntemlerini uygulamışlar. Hastalar günde 2 kez 3 hafta boyunca 5-fluorouracil kremile, \%30 triklorasetik asit peelingi ile ve tüm yüz CO2 lazer ile tedavi edilmişler. Hastalar 3 ay aralıklarla 2 yıl boyunca 
takip edilmişler. Tüm tedavi teknikleri kontrollere göre aktinik keratoz ve nonmelanoma deri kanser sayısında azalma sağladılar. Üçüncü ayda lazerle tedavi edilmiş hastalarda Aktinik keratoz sayısında \%92 azalma saptanmış. Lazerle tedavi edilen hastalarda kanser insidans hızı (yıl içinde hasta başına düşen yeni nonmelanom deri kanseri sayısı) 0,15 idi ki bu değer tedavi edilmemiş kontrollerde 1,57 imiş. Hiçbir alanda belirgin bir yan etki gözlenmemiş. Otörler, her 3 yöntemin de aktinik keratoz ve nonmelanoma deri kanserlerin azaltılmasında etkili olduklarını; bunakarşın trikloroasetik asit peelinginin en düşük kanser insidans hızına $(0,04)$ ve en yüksek hasta memnuniyetine sahip olduğu sonucuna varmışlar. CO2 lazerler, epitel atipi derecesini azaltmakta etkili olabilmekle beraber, etkileri sınırıdır. Atipik keratinositler, ablasyon derinliğinden daha derindeki folliküler epitelyuma doğru ilerleyebilirler ve iyileşme döneminde tekrar epidermisde yerleşebilirler. Su molekülü hedef kromofor olduğundan; hiperkeratozik aktinik keratozlar tedaviye direnç gösterebilir ve önceden inceltilmeleri gerekebilir.Kalın keratotik lezyonların, cilt yenileme işlemi öncesi kurete edilmeleri gerekir. Topikal tedavilerin tedaviden 6-8 hafta öncesinde uygulanması yüzey kalınlığını azalııp, teropötik yanıtı arttırabilir 12 .

\section{Nonmelanoma Deri Kanserlerinin CO2 Lazer ile Destrüksüyonu}

Premalign lezyonların tedavilerinde kullanılmaları yanında, CO2 lazer nonmelanom deri kanserlerinin eradikasyonunda da kullanılmışlardır. Özellikle antikoagülan kullanan hastalarda ve çok sayıda lezyonu olup cerrahiye uygun olmayan hastalarda diğer tedavi alternatiflerine bir üstünlük sağlar. Ayrıca iyileşme sürecinin daha kısa olması ve daha kozmetik sonuçlar sağlaması diğer avantajlarıdır.33 Histopatolojik incelemenin yapılamaması ve ilave ekipman gerektirmeleri ise dezavantajlarıdır34

Humphreys ve arkadaşlarının açık prospektif bir analiz çalışmasında35; 30 yüzeyel neoplazmada (17 Bazal hücreli karsinom ve 13 skuamöz hücreli karsinoma insitu) CO2 lazerin etkinliğini incelediler. Neoplazmalar 2 veya 3 lazer geçişiyle çevrede $3 \mathrm{~mm}$ normal dokuyu da içerecek şekilde CO2 lazer uygulanıp, daha sonra $1 \mathrm{~mm}$ sınırla histolojik inceleme için çıkarıldılar. Üç lazer geçişi uygulanan Bazal hücreli karsinoma olgusu histolojik olarak temiz iken, 2 lazer geçişi uygulanan 8 bazal hücreli karsinoma olgusunun $5^{\prime}$ in alt sınırında tümör artığı saptandı. Skuamöz hücreli karsinoma in situ'su olan 13 olgunun 5'inde geçiş sayısına bağlı olmaksızın, alt sınırında pozitif tümör artığı saptandı. Bu bulguların ışığı altında otörler; yüzeyel Bazal hücreli karsinomların tedavisinde 3 lazer gecişini ve $4 \mathrm{~mm}$ marjinin de tedavisini tavsiye etmektedirler. Skuamöz hücreli karsinomlarda sıklıkla bulunan azalmış su miktarı ve hiperkeratoz, Bazal hücreli karsinomlara kıyasla tedaviye yanııı daha az olasında önemli gibi gözükmektedir ve Skuamöz hücreli karsinomların tedavisinde tek başına CO2 lazer tedavisini pek tavsiye etmemektedirler. Takip eden çalışmalar, süperfisyal ve nodüler bazal hücreli karsinomların ablasyonunda superpulse CO2 lazerin etkinliğini desteklemişlerdir34. Yüzeyel veya nodüler Bazal hücreli karsinomu olan 140 hasta çevre dokuda $2 \mathrm{~mm}$ sınır ile derin dermise kadar CO2 lazer ile tedavi edildiler. Üç yıllık takipte rekürrens görülmedi ve iyi estetik sonuçlar elde edildi. Diğer uzun takip süreli bir çalışmada36, 61 Bazal hücreli karsinomu olan 23 hastada pulse CO2 lazer uygulaması ile mükemmel bir iyileşme oranı sağlandı. Bazal hücreli karsinomlara 4-6 mm sınır ile, 2-8 lazer geçişi uygulandı. Ortalama 41,7 aylık takip sonrasında sadece 2 rekürrens bildirildi. Yan etkiler minimal olup; 1 olguda hipertrofik skar ve 1 olguda da hipopigmentasyon gelişmiş. Sonuçlar, elektrodesikasyon veya kürataja göre daha fazla kozmetik üstünlük göstermiş. CO2 lazer, yüzeyel ve nodüler
Bazal hücreli karsinomları etkili ve kansız bir şekilde ablate edebilmelerine rağmen, 2 lazer geçişinden fazla geçiş gerektiğinde hipo- ve hiperpigmentasyon oldukça sık görülen bir sekeldir. Sınırlı termal hasar oluşturmasından dolayı elde edilen kozmetik sonuç elektrodesikasyon ve küretaja göre daha iyidir.Bunakarşın, kriyoterapi veya fotodinamik tedavi gibi yeni tedavi modelleri ve topikal imiquimode kozmetik üstünlüğü ve etkinliği net değildir.

\section{Kutanöz Hamartomlar}

Epidermal nevusler için değişik tedaviler, değişken sonuçlar ile bildirilmiştir. Daha önceki tedaviler; dermabrazyon, kriyoterapi, eksizyon, retinoidler, steroidler ve topikal 5-fluorourasil'i içermektedir37. Bu tedavilerin çoğu skar veya yetersiz temizlenme ile sonuçlanmaktadır. Aynı lezyon içinde değişik derinliklerde tutulum olabildiğinden, pulse CO2 lazer idel bir tedavi imkanı sağlayabilmektedir. Lazer uygulayıc lezyonun derin bölgelerinde daha fazla geçis, yüzeyel bölgelerinde daha az sayıda geçiş yaparak tedaviyi yönlendirebilmektedir. Buna karşın etkiyi arttırabilmek için çok sayıda geçiş yapılması skar riskini de doğurduğundan uygulayıcıya bunu dengeleme stresi yaratabilmektedir. Michel ve arkadaşları38; superpulse CO2 lazer ile tedaviden 2 yıl sonra 10 epidermal nevusden 4 'ünde tam rezolüsyon saptadılar. Ufak bir bölgede rekürrens 2 olguda ve hiperpigmente skar 1 olguda görüldü. Boyce ve Alster ${ }^{37}$; pulse $\mathrm{CO} 2$ ile 3 epidermal nevus tedavi ettiler ve tedaviden 1 yıl sonra 3'ünde de iyi yanıt bildirdiler. Bir hastada ufak bir alanda rekürrens saptandı, skar görülmedi.

\section{Akantolitik Hastalıklar}

Hailey-Hailey ve Darier-White Hastalığı gibi akantolitik hastalıkların tedavisinde $\mathrm{CO} 2$ lazer başarıyla kullanılmıştır. Bazı olgu ve seri çalışmalarında CO2 lazer tedavisi sonrası Hailey-Hailey'e sekonder deri hasarlarında azalmalar bildirilmiştir39. Başarı ile tedavi edilen alanların atrofik skarlar ile yer değiştirdiği görülmektedir. Uzun süreli takiplerde fokal relapslar bildirilmektedir. Rekürren lezyonların biopsilerinde folliküler akantolizis odakları görülmüştür. Bu nedenle otörler, Darier hastalığında rekürrensleri engellemek için, folliküllerin tamamen ablasyonunun gerekliliğini savunmaktadır. Akantolitik tablonun rezolüsyonu sıklıkla skatris ile birliktedir 39 .

\section{Diğer Tıbbi Endikasyonlar}

Rinofiması olan 124 hasta CO2 lazer ile (Sharplan Lasers UK Ltd, London, U.K.) tedavi edilmiş. CO2 lazer devamlı moda ve cilt yenileme modunda kombine olarak uygulanmış. Tedaviden 3 ay sonraki değerlendirmede 118 hasta iyi ve çok iyi sonuç bildirirken, 6 hasta zayıf yanıt bildirmiş. 4 hastada hipopigmentasyon ve skar, 2 hastada por genişlemesi saptanmış ${ }^{40}$. Port Wine malformasyonların hipertrofik ve nodüler komponentlerinde etkili bulunmuş.41, buna karşın ileri yaşlarda dirençli olgular da bildirilmiş42. Vitiligo tedavisinde greft öncesi dokunun hazırlanması için ablative lazer sistemleri kullanılabilir43. Diğer tedavilerle kombine edilebilir44. Tuberoskleroza bağlı anjiofibromlarda başlangıçta iyi yanıt vermesine rağmen uzun vadede etki net değildir. 10 olguluk bir çalışmada 6 ay sonrası sonuçlar iyi iken az sayıldaki olguda 24 ay sonra etki devam etmiştir. Buna karşın hasta memnuniyet oranı yüksek saptanmıştı ${ }^{45}$. Strialar üzerinde de etkili olduğunu gösteren çalışmalar mevcuttur46. Siğiller üzerinde değişken sonuçlar bildiren çalışmalar mevcuttur. Bir çalışmada, 22 hastanın 71 dirençli verrüsüne tek seans CO2 lazer tedavisi sonrası \%54,5 hastada tam 
remisyon saptanmış. Takipte 5,29 ayda rekürrensler saptanmış. Bu olguların \%90'ı başarılyla tedavi edilmiş. \%46,7 olguda skar saptanmasına rağmen hastalar tarafından iyi tolere edilmiş.Olguların \%80'i tekrar tedavi gerektirmiş.4 olguda, tedavi edilmeyen bölgedeki verrü lezyonlarında spontan gerileme saptanmış ${ }^{47}$. Diğer bir çalışmada 31 hastadaki 35 plantar verrü lezyonuna CO2 lazer ile insizyon ve arkasından oluşan defekte artifisyal dermis uygulanması ile tek seans sonrası 35 lezyonda $(\% 88,6)$ tam temizlenme saptanmış. 4 olguda $(\% 11,4)$ lokal rekürrens saptanmış48.

\section{Erbium:Yttrium-Aluminım-Garnet Lazer ile Cilt Yenileme}

Erbium:yttrium-aluminım-garnet (Er:YAG) lazer , kütanöz cilt yenilenme için 1996 'da FDA onayı almıştır. Kısa atım süreli CO2 lazer ile kıyaslandığında, daha ince bir ablasyon ve termal hasar zonuna sahiptir ki, bu yara iyileşme sürecini kısaltır ve işlem sonrası yan etki oranını azaltır. Kısa-atım süreli Er:YAG lazer (250-350 milisaniye) ilk form olup, daha sonra 1999'da değişken (variable) ve uzun-atım süreli Er:YAG lazerler (500 mikrosaniye-10 milisaniye) geliştirildi1,2,5,12. Er:YAG lazer, hedef kromofor olan su tarafından daha fazla absorbe edildiğinden HEPCO2 'e kıyasla daha farklı bir doku reaksiyonu gösterir. Er:YAG lazer, 2940 nm dalgaboyunda ,flashlamp kaynaklı kristal lazerlerdendir. Dalgaboyu, "su" molekülünün absorbsiyon pikine (3000 nm) yakın olduğundan, enerjinin çoğu epidermis ve papiller dermis tarafından absorbe edilir ve HEPCO2 lazerle kıyaslandığında daha yüzeyel bir ablasyon ve çevre dokuda daha az termal hasara neden olur. Bu nedenle çok sayıdaki geçişle uygulanan Er:YAG lazer, ablasyon zonu çevresinde artan bir termal hasar zonuna neden olmaz. Kısaatım süreli Er:YAG lazerin her geçişinde yaklaşık olarak 20-25 mikronluk doku ablasyonunu $\left(5 \mathrm{~J} / \mathrm{cm}^{2}\right)$ oluşur.Termal hasarın derinliğinin ise 30-50 mikron (5-7 J/ $\mathrm{cm}^{2}$ ) olduğu gösterilmiştir. CO2 lazer için bu termal hasar ise 50-200 mikron civarındadır $\left(3.5-6.5 \mathrm{~J} / \mathrm{cm}^{2}\right)$. Çok sayıdaki Er:YAG lazer geçişine rağmen, çevredeki termal hasarı pek fazla artmayıp 50 mikron civarında kalmaktadır.Buda kollajen uyarımının CO2 lazere kıyasla daha az olmasıyla karakterizedir 1,2,12

Daha sonra geliştirilen uzun-atım süreli (10 milisaniye) Er:YAG lazer, ablasyon çevresindeki termal hasar zonunu yaklaşık 60 mikrona artırmaktadır. Bu daha fazla kollajen kontraksiyonuna ve kırısı ılık azalmasına neden olurken, eritem ve hiper/hipopigmentasyon gibi yan etki riskini arttırmaktadır1,2,12.

\section{Fotoyaşlanma ve Kırışıklıklarda Kozmetik Uygulamalar}

Kısa-atımlı Er:YAG lazer ile ilgili ilk deneyimler, bu lazer ile yapılan cilt yenilemelerde HEPCO2 lazerler ile yapılan cilt yenilemeye kıyasla yara iyileşme sürecini kısalttıkları ve postoperatif eritemin daha hafif ve kısa süreli olduğunu desteklemiştir. Teikemeier ve Goldberg 49; kısa-atımlı Er:YAG lazer (350 mikrosaniye, 2.5-5 spot,400-800 mJ) ile tek geçiş sonrası reepitelizasyonun 4-10 günde gerçekleştiğini, eritemin 2 haftadan daha kısa sürede geçtiğini bildirmişlerdir. Pigment değişikliği ve skar görülmemiş ve hastaların hepsinde de kırışıklıklarda klinik iyileşmeler saptanmış. Benzer sonuçlar Perez ve arkadaşlarının 50, kısa-atımlı Er:YAG lazer $\left(4-5 \mathrm{~J} / \mathrm{cm}^{2}\right.$, 250-350 ms, 5mm spot) uyguladıkları 15 hastada bildirilmiş.Ortalama iyileşme süresi 3.2 gün,kırmızılığın pembe renge dönme süresi 7.1 gün ve eritemin tamamen gerileme süresi 3-6 hafta olarak bildirilmiş. 15 hastanın 8'inde belirgin düzelme (Klas I-II kırışıklıkların \%50-75'i başarılı) ve 6'sında orta seviyede düzelme ( Klas I-II kırışıklıkların \%25-50'si başarılı) saptanmış. Khatri ve arkadaşları 51; yüz cilt yenilenmesi amacıyla, kısa-atımlı Er:YAG lazeri (300 ms,5mm spot,5 veya $10 \mathrm{~J} / \mathrm{cm}^{2}$ ) tüm yüze, tek seans olarak uygulamışlar.Hastalar sadece topikal anestezi ile lazere hazırlanmış.
Hastalarda $10 \mathrm{~J} / \mathrm{cm}^{2}$ dozunda sadece hafif bir rahatsız his ve eritem saptanmış. 1 ila 5 arası değerlendirmede; $5 \mathrm{~J} / \mathrm{cm}^{2}$ dozunda 1. haftada 1,8, 1. ayda 2,1 ve 3 . ayda 1,7 değer saptanırken; $10 \mathrm{~J} / \mathrm{cm}^{2}$ dozunda sırasıyla 1,6, 2,5 ve 2,1 değerler saptanmış. Farklı 2 Er:YAG lazeri (Sciton kısa-atımlı Er:YAG ve Cynosure CO3 lazer) karşılaştıran bir çalışmada 52; etkinlik birbirlerine yakın bulunmuş.Tüm yüze, lokal anestezi altına 1 geçiş ardından periorbital ve perioral bölgelere eksta 2. ve 3. geçişler yapıldı. Pigment düzensizliklerinde $\% 58$ ve cilt yapısında $\% 54$ düzelme saptanmış. Üç ay sonunda perioral ve periorbital bölge kırışıklıklarında \%43 düzelme saptanmış. Uzun süreli sonuçlar açısından lazerler arasında fark saptanmamış. Hastalar 3 gün sonra işlerine dönebilmişler ve eritem 5 günde gerileme göstermiş.Uzun süreli bir yan etki saptanmamış.

Kısa-atımlı Er:YAG lazer uygulamalarından önce; lazer ile cilt gençleştirme işlemler skar ve dispigmentasyon risklerinden dolayı sadece yüz bölgesi ile sınırlıydı.Goldman ve arkadaşları53; boyun bölgesinin canlandırılması için, 20 hastaya 2 geçişli kısa-atımlı Er:YAG lazer uyguladılar. 3 ay sonraki gözlemlerde deri yapısında \%38 ve deri renginde \%37 düzelme saptadılar. 6 hafta sonraki histopatolojik incelemelerde yeni dermal kollajende artma ve distrofik epidermisde normalleşme saptandı. Kalıc bir yan etki saptanmadı.

Er:YAG lazerlerde atım süresinin uzatılması; ablasyon zonunun altında daha fazla dokuyu ısıtarak lazerin klinik etkinlğini artııırken, potansiyel yan etki riskini de arttırmaktadır.Uzun-atımlı Er:YAG lazerler ile cilt yenilemede, postoperatif eritem şiddetinde hafif bir artma saptanırken, kısa-atımlı Er:YAG lazerinki ile benzer reepitelizasyon süresi göstermektedir. Farklı iki atım süresi (tek geçiş, 0,5 milisaniye ve 4,0 milisaniye, $7 \mathrm{~J} / \mathrm{cm}^{2}$ ) kullanılarak 6 hasta üzerinde yapılan bir çalışmada 54; ortalama reepitelizasyon süresi 3.6 gün iken, hastalar 4 günde işlerine dönebilmişler. Posoperatif 7 . günde yara iyileşme ve eritemde belirgin bir fark saptanmamış, bunakarşın 4 milisaniye uygulanan bölgede posoperatif 3 ve 4 . günde eritem daha fazlaymış.

\section{Yan Etkiler ve Pigmente Deride Kullanımı}

Lazer ile cilt gençleştirme işlemleri, cihaza bağımlı olmaksızın, hiperpigmentasyon, hipopigmentasyon, skar oluşumu ve herpes simpleks virus aktivasyonları gibi komplikasyonlar gösterebilir. Pigment değişikli riski çok fazla olduğundan, Fitzpatrick deri tipi III ve üstü hastaların çoğunda $\mathrm{CO} 2$ lazer ile cilt yenileme tavsiye edilmemektedir. Pigment düzensizliklerinin riskini azaltmadaki avantajları nedeniyle, pigmente deride de, CO2 lazere göre daha uygundurlar. Pakistandaki bir çalışmada55; yüz bölgesinde skar veya kırısıklıkları olan, deri tipi IV hastalara kısa-atımlı Er:YAG lazer ile (250 mikrosaniye, 0,8-1 J/cm², 4-8 geçiş, 5 mm spot) cilt yenileme uygulanmış. Üç ay sonrasında hiçbir hastada hiperpigmentasyon görülmezken, 6'sında hafif hipopigmentasyon saptanmış.Orta ila çok iyi düzelmeler \%80 olguda gözlenmiş. Çalışmacılar, kısa-atım süreli Er:YAG lazerin, deri tipi yüksek hastalarda etkili ve güvenli olduğu yorumunu yapmışlar. Bir Kore çalışmasında 56; yüzde akne skarları ve suçiçeği skarları olan 190 hastaya (deri tipi III-IV) kısa atım süreli Er:YAG lazer (4-5 geçiş,350 mikrosaniye, 2 mm spot, 12,5-15 J/cm²), çift modlu değişken-atımlı Er:YAG

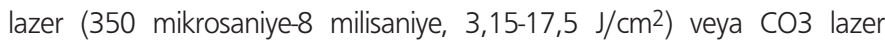
(4-5 geçiş, 7 milisaniye, $5 \mathrm{~mm}$ spot,7-7,5 J/ $\mathrm{cm}^{2}$ ) uygulanmış. Hiperpigmentasyon \%38 olguda görülmüş ve 16 haftada \%93'ü gerilemiş. Hipopigmentasyon \%13,7 olguda görülmüş ve \%85'i 1 yıl içinde gerilemiş. Atım süresinin uzatılması, hipopigmentasyon ve hiperpigmentasyon oranının artmasıyla uyumlu bulunmuştur. Kısa-atım süreli Er:YAG lazerle tedavide en az hiperpigmentasyon ve hipopigmentasyon oranı saptanmış. 
Tanzi ve Alster 57; deri tipi I-V olan, kırışıklık, fotoyaşlanma ve atrofik skarı olan 50 hastaya uyguladıkları değişken-atımlı Er:YAG lazer ile cilt yenileme sonrası \%40'a yakın hiperpigmentasyon oranı bildirdiler. Eritem tüm hastalarda görüldü, fakat sadece 3 olguda 1 aydan fazla kaldı.Diğer yan etkiler; akne (\%16), milia (\%10) ve dermatit (\%6) idi. Tanzi ve Alster 58; CO2 lazer ve Er:YAG lazer ile cilt yenilemenin reepitelizasyon zamanları ve yan etki profillerini 100 hastalık bir seride retrospektif olarak incelediler. Hastaların yarısı tek geçişli CO2 lazer (300mJ,60W,CPG) , diğer yarısı da 23 geçişli uzun-atım süreli Er:YAG lazer (90 mikron ablasyon, 50 mikron koagülasyon) tedavisi aldı. Reepitelizasyon süresi, CO2 lazer tarafında 5.5 gün iken, Er:YAG lazer tarafında 5.1 gün idi.Eritem, CO2 lazer tarafında ortalama 4.5 hafta sürerken, Er:YAG lazer tarafında 3,6 hafta sürdü. Hiperpigmentasyon, CO2 lazer tafında \%46 iken, Er:YAG lazer tarafında \%42 idi. Bu sonuçlar, tek geçişli CO2 lazer ile multiple geçişli Er:YAG lazerin, yara reepitelizasyonu ve postoperatif yan etkiler göz önüne alındığında birbirine yakın etki gösterdiği yorumunu getirmiştir.

\section{Er:YAG Lazer Terapotik Uygulamalar}

Er:YAG lazerin ablatif özelliği kozmetik uygulamalar dışında, benign, premalign ve malign deri lezyonlarında da kullanılmıştır. Khatri59; 27 hastadan 363 kütanöz lezyonun tedavisinde kısa-atımlı Er:YAG lazeri kullanmış.Lazer geçişleri lezyon tamamen kaybolana kadar uygulanmış. Bu protokol ile \%2,2 relaps bildirilmiş. Diğer bir çalışmada 60; 14 hastanın 28 akkiz melanositik nevusüne (deri tipi II-III) kısa-atım süreli Er:YAG lazer uygulanması sonrası 27'sinde klinik ve histopatolojik olarak tam temizlenme sağlanmış. Lezyon çapları 6 mm'den fazla değilmiş. Iki hastada hiperpigmentasyon, 3 hastada hipopigmentasyon gelişmiş ve skar saptanmamış. Epidermal nevusü olan 6 hasta 2940 nm erbium:YAG lazer ile tedavi edilmiş. 6-60 ay takiplerde kozmetik sonuçlar çok iyi imiş61.

Malignant potansiyeli olduğu bilinmesine karşın çok erken evrelerde Konjenital nevüslere ablatif tedavi öneren çalışmacılar da mevcuttur. Bir çalışmada konjenital melanositik nevusü olan 10 neonatale doğumlarının ilk haftasında Er:YAG lazer uygulanmış. Hastalar lazeri iyi tolere etmiş ve ilk izlenimler iyi imiş. 3-36 ay takiplerde 10 hastanın 8'inde hafif veya hiç repigmentasyon saptanmamış. Posop ağrı, kanama ve skar düşük oranda saptanmış. Biopsilerde dermisin üst bölümlerinde yoğun pigmente hücrelerin kaybolduğu görülmüş62.

Değişik tipte skarları olan 36 hastaya (12 hipertrofik, 20 deprese ve 4 yanık skarı) Er:YAG lazer uygulanmış. On iki hipertrofik skarın 9'unda, 20 deprese skarın 17'sinde ve 4 yanık skarının 2'sinde \%50'den fazla iyileşme gözlenmiş. Deprese skarlı bir hastada 3 ay sonrasında hiperpigmentasyon saptanmış, deprese skarlı bir hasta ve yanık skarlı hastaların hepsinde, lazerden 4 ay sonrası hafif bir eritem kalmış63.

Tedavisi zor siğilleri olan (periungual veya plantar verrü) 69 hastaya Er:YAG lazer uygulanmış50. Hastada tam düzelme saptanırken plantar verrüler daha dirençli saptanmış (plantar verrüde \%13,5 yanıtsızık, periungual verrüde \%5,9 yanıtsızlık). Tam yanıt gösteren olguların 12'si tedaviden 3 ay sonra tekrarlamış64.

\section{Er:YAG Lazer ile CO2 Lazer Ablasyonunun Kombinasyonu}

Bazı lazer uygulayıcıları; Er:YAG lazerin ablasyon hakimiyetinden dolayı yüzeydeki kömürleşme ve debrisin az olmasının daha hızlı bir reepitelizasyon sağlamasına rağmen, dermal yeniden yapılanmanın derecesini belirleyen asıl önemli faktörün ablasyon derinliğinden ziyade termal hasar derinliği olduğunu vurgulamaktadırlar. Bu nedenle bazı uygulayıcılar daha az bir kömürleşmiş termal koagüle doku ve daha hızlı bir yara iyileşmesi için önce yüksek enerjili atımlı CO2 lazer uygulayıp (HEPCO2), arkasından son geçişleri Er:YAG lazerle tamalamayı denemişlerdir. McDaniel ve arkadaşları65 üst dudak kışışıklıklarında tek başına HEPCO2 ile kombine CO2/Er:YAG yaklaşımını kıyaslamışlar. Eritem ve ağrıda farklılık saptanmazken, kabuklanma ve kaşıntı kombine sistemde daha az saptanmış. Her iki tekniklede de kırışıklıklarda benzer etki saptanmış. Kalı ı bir hiper- veya hipopigmentasyon veya skar saptanmamış. Trelles ve arkadaşları66; 102 hastalık bir seride kombine Er:YAG sistemi ile \%90 'a yakın iyi ve çok iyi yanıt bildirmiş ve biopsilerde sağlam kıl follikülleri ile birlikte minimum veya hiç karbonizasyon saptanmıştır.

\section{CO2 Lazer ve Er:YAG Lazer'in Karşılaştırmalı Çalışmaları}

Başlangıçta Er:YAG lazerlerin daha çok hafif veya orta derecedeki kırısıklıklarda etkili olabilecekleri şeklinde genel bir kanı varken, daha sonra geliştirilen yüksek enerjili yeni cihazlar ve klinik tecrubeler, artık bu lazerlerin derin kırışıklık ve akne izlerinde de HEPCO2 lazerlere eşit veya daha iyi etki edebileceğini göstermektedir. Çoğu otör, Er:YAG lazerlerin etkinliklerinin CO2 lazere eşit düzeyde olduğu, bunakarşın çevre dokuda daha az termal hasar ve daha kontrollu hasar değinliği sağlamasından dolayı da yan etkilerinin daha az olduğuna inanmaktadırlar67. Bu otörler, diğerlerinin aksine dermal yeniden yapılanmada çevre dokudaki termal hasardan ziyade ablasyon derinliğinin daha önemli olduğunu ve bu nedenle Er:YAG lazerin üstülüğünü savunmaktadırlar.

Khatri ve arkadaşları68; perioral ve periorbital kırışıklığı olan, deri tipi I-III 21 hastada kısa-atım süreli Er:YAG lazer ile CO2 lazerin cilt yenileme etkilerini karşılaştırdıkları bir çalışmada ; benzer fluens ve geçiş sayısında Er:YAG lazerin daha yüzeyel bir ablasyon ve daha hızlı bir yara iyileşmesi gerçekleştirdiği, bunakarşın etkinliğinin daha az olduğunu gösterdiler.5 üzerinden değerlendirmede 3 geçiş CO2 lazer sonrası skor 4,0 iken, 5 geçişden az Er:YAG lazer sonrası skor 2,0 idi. İki ve 8 hafta değerlendirmede postoperatif eritem Er:YAG lazerde daha azdı (\%67 vs\%95 ve \%24 vs \%62). Her iki bölgeden alınan biopsilerde; Er:YAG lazer bölgesinde residüel temal hasar maksimum 50 mikron iken, CO2 tarafında maksimum 200mikron civarında idi. Çalışmacılar; kısa-atım süreli Er:YAG lazerin, yüzeysel cilt yenileme için ve belirgin eritem veya iş-güç kaybını tolere edemeyecek hastalar için daha uygun olduğu yorumuna varmışlardır.

Uzun-atım süreli Er:YAG lazerin sonuçlarının, HEPCO2 lazerinkine yakın görünmektedir. Adrian69, periorbital kırışıkıklarda uzun-atım süreli Er:YAG lazer (10 milisaniye, $5 \mathrm{~mm}$ spot, $5 \mathrm{~J} / \mathrm{cm}^{2}, 10-12$ geçiş) ile HEPCO2 lazeri (300 mJ, CPG dansite 5,3 geçiş) karşılaştırdılar. Hasta ve hekim değerlendirmelerinde benzer sonuçlar saptandı.

\section{0 nm YTTRIUM Scandium Gallium Garnet Lazer (YSGG)}

2790 nm YSGG lazer, diğer ablatif lazerlerin töropatik dezavantajlarının üstesinden gelebilmek için üretilmiştir ve ablasyon ile termal etki arasında sinerjiyi hedeflemektedir. Bu şekilde hasta iş-güç kaybını azaltırken, gerekli tedavi seansını da azaltmaktadır. Kristal Erbium: yttrium - scandium - gallium-garnet (Er:YSGG) lazer 2790 nm dalgaboyunda olup, bu dalgaboyunun su absorbsiyon katsayısı 2940 nm Er:YAG lazer ile 10600 nm CO2 lazerinkinin arasındadır.Bunun sonucu olarak $2940 \mathrm{~nm}$ Er:YAG lazerden daha fazla koagülasyon ve termal stimülasyona neden olurken , 10600 nm CO2 lazerden daha az bir termal hasar ve sınırlı derinliğe neden olabilmektedir10,11. 
2790 nm Erbium:yttrium-scandium-gallium-garnet (Er:YSGG) lazer, Cutera tarafından Pearl ticari adıyla ilk olarak 2007 yılında estetik amaçlı olarak üretildi. 10600 nm CO2 lazer ve 2940 nm Er:YAG gibi ablatif cilt yenileme lazerlerinde olduğu gibi , 2790 nm YSGG lazer de kromofor olarak derinin üst $1 \mathrm{~mm}$ 'si içindeki "su" molekülünü hedefler.Klinik olarak, Pearl ile yüzeyel cilt yenileme, yüzeyel kahverengimsi epidermal diskromilerin ve yüzeyel ince kırısıklık ve skarların tedavisinde etkili ve iyi tolere edilebilir bulunmuşlardır. Bu olgular için 1 veya 2 seans YSGG lazer yeterli olabilirken, diğer taraftan benzer bir etki için 3-6 seans IPL tedavisi gerekebilmektedir. Pearl Fraksiyonel lazer de; diskromilerde, derin kırışıkıklarda ve orta derinlikteki akne skarlarında çok iyi sonuçlar vermiştir. 2790 nm Er:YSGG lazer cihazı, hem ablatif (konflue) hem de fraksiyonel ablatif kapasiteyi aynı seans içinde kombine edebilmektedir. Kombine tedavi; tüm yüzeyel epidermisin buharlaşmasına, derin epidermisin koagülasyonuna ve derin dermisde fraksiyonel koagülasyona neden olur. Bu kombinasyon ablatif lazer tedavisine bağıı iş-güç kaybını azaltırken, fraksiyonel ablatif lazer tedavisinin güvenirliliğini artırır10,11. Bu iki, ablatif ve fraksiyonel tedavi formu, tüm yüzde veya yüzün belirli bölümlerinde, aynı seansda kombine edilebilirler10,11.

Hastalarda ilk 48-72 saatte en yoğun enflamasyon ve eritem görülür. 4-7 gün boyunca güneş-yanığı benzeri bir reaksiyon iş-güç kaybına neden olur, 1-3 hafta eritem devam edebilir, ki bu dönemde kozmetiklerle kapatma kullanılabilir. Etki ortalama 3 haftada görülmeye başlayabilmekle beraber, maksimum etkiye tedaviden 3-6 ay sonra ulaşılır. Biesman B'nin çalışmasında16 fotoyaşlanması olan 10 hastaya kombine ablatif (konflue) ve fraksiyonel $2790 \mathrm{~nm}$ Er:YSGG lazer tek seans olarak uygulandı. Olguların \%90' । klinik iyileşme gösterirken, 6 ay sonraki takipte \%78'inde etki devam etmekteydi.1 olguda iyileşme gözlenmedi. Lazer sonrası görülen hafif eritem, tüm olgularda 6 haftada kayboldu.Geçici veya kalıcı postenflamatuar hiperpigmentasyon veya ciddi bir yan etki gözlenmedi. Sonuç olarak ablatif lazerler artık yerlerini fraksiyonel ablatif lazerlere (Fraksiyonel CO2, Er:YAG ve Er:YSGG) bırakıyor görünmekle beraber, uygun hasta seçimi ve özellikle de tıbbi birtakım endikasyonlarda önemlerini korumaktadırlar.

\section{Kaynaklar}

1. Nelson AA, Lask GP: Principles and practice of cutaneous laser and light therapy.Clin Plast Surg 2011;38:427-36.

2. Tull SS, Raza S: Lasers \& light therapies for skin rejuvenation. Mo Med 2011;108:69-72.

3. Aybey B, Ergenekon G: Deri kırısıklıklarının tedavisinde ablatif cilt yenileme lazerleri ve kullanımı. Türkiye Klinikleri J Cosm Dermatol-Special Topics 2009:2:47-54

4. Rinaldi F: Laser: a review. Clin Dermatol 2008;26:590-601.

5. Railan $\mathrm{D}$, Kimler S: Ablative treatment of photoaging.Dermatologic Therapy 2005;18:227-41.

6. Anderson RR, Parrish JA: Selective photothermolysis.Precise microsurgery by selective absorbtion of pulsed radiation. Science 1983;22:524-7.

7. Hantash BM, Gladstone HB: Current role of resurfacing lasers. G Ital Dermatol Venereol 2009;144:229-41.

8. Alster TS: Cutaneous resurfacing with $\mathrm{CO} 2$ and Erbium:YAG lasers: Preoperative, intraoperative, and postoperative considerations. Plast Reconst. Surg 1999;103:619-34.

9. Zachary CB: Modulating the Er:YAG laser. Lasers Surg Med 2000;26:223-9.

10. Ross EV, Swann M, Soon S, et al: Full-face treatments with the $2790 \mathrm{~nm}$ erbium:YSGG laser system. Drugs Dermatol 2009;8:248-52.

11. Smith KC, Schachter GD: YSGG $2790 \mathrm{~nm}$ superficial ablative and fractional ablative laser treatment. Facial Plast Surg N Am 2011;19:253-60.

12. Riggs $K$, Keller M, Humphreys TR: Ablative laser resurfacing: high-energy pulsed carbon dioxide and erbium:yttrium-aluminum-garnet. Clin Dermatol 2007;25:462-73.
13. Krupashankar DS: Standard guidelines of care: $\mathrm{CO} 2$ laser for removal of benign skin lesions and resurfacing.Indian I Dermatol Venereol Leprol 2008;74: Suppl:S61-7.

14. Horton S, Alster TS: Preoperative and postoperative considerations for cutaneous laser resurfacing. Cutis 1999; 64:399-406.

15. Duke D, Grevelnik JM0 Care before and after laser skin resurfacing : A survey and review of the literature. Dermatol Surg 1998;24:201-6.

16. Biesman B: Combining confluent and fractionally ablative modalities of a novel 2790nm YSGG laser for facial resurfacing. Lasers Surg Med 2011;43:273-82.

17. DiBernando B: Assesment of the impact of high-fluence,high-overlap settings on full face treatments with the $2790 \mathrm{~nm}$ Pearl YSGG laser. Laser Surg Med 2008:40:34.

18. Walgrave SE, Kist $D$, Cham PMH, Zelickson BD: Minimally ablative resurfacing with the confluent $2790 \mathrm{~nm}$ Erbium:YSGG laser .A pilot study on safety and efficacy. Laser Surg Med 2009;41.41.

19. Perez M, Lupo M: Improvement after minimally ablative resurfacing with the confluent $2790 \mathrm{~nm}$ YSGG laser:A survey of 44 fee-for-service patients and their treating physicians.Laser Surg Med 2009;41:110.

20. Yu C, Negishi K, Shek S, Chan N, Chan HH: A prospective multi-center clinical study of photo rejuvenation in Asian skin using $2790 \mathrm{~nm}$ infrared laser. Laser Surg Med 2009;41:42.

21. Goldberg D, Ciocon D, Engelman D, Hussain M: Treatment of peroral rhytides with a new fractionated ablative Er:YSGG(2790 nm) laser. Laser Surg Med 2010;42:24.

22. Tanzi EL,Alster TS: Single-pass carbon dioxide versus multiple-pass Er:YAG laser skin resurfacing:A comparison of postoperative wound healing and side-effect rates. Dermatol Surg 2003;29:80-84.

23. Alster TS, West TB: Resurfacing of atrophic facial acne scars with a highenergy, pulsed carbon dioxide laser. Dermatol Surg 1996;22:151-4

24. Schwartz RJ, Burns AJ, Rohrich RJ, Barton FE Jr, Byrd HS: Long-term assessment of $\mathrm{CO} 2$ facial laser resurfacing: aesthetic results and complications. Plast Reconstr Surg 1999;103:592-601.

25. Bisson MA, Grover R, Grobbelaar AO: Long-term results of facial rejuvenation by carbon dioxide laser resurfacing using a quantitative method of assessment. Br J Plast Surg 2002;55:652-6.

26. Manuskiatti W, Fitzpatrick RE, Goldman MP: Long-term effectiveness and side effects of carbon dioxide laser resurfacing for photoaged facial skin.J Am Acad Dermatol 1999;40:401-11.

27. Walia S, Alster TS: Prolonged clinical and histologic effects from CO2 laser resurfacing of atrophic acne scars. Dermatol Surg 1999;25:926-30.

28. Nehal KS, Levine VJ, Ross B, Ashinoff R: Comparison of high-energy pulsed carbon dioxide laser resurfacing and dermabrasion in the revision of surgical scars. Dermatol Surg 1998:24:647-50.

29. Ostertag JU, Quaedvlieg PJ, Neumann MH, Krekels GA: Recurrence rates and long-term follow-up after laser resurfacing as a treatment for widespread actinic keratoses on the face and scalp. Dermatol Surg 2006;32:261-7.

30. Sherry SD, Miles BA, Finn RA: Long-term efficacy of carbon dioxide laser resurfacing for facial actinic keratosis. J Oral Maxillofac Surg 2007;65:1135-9.

31. Iyer S, Friedli A, Bowes L, Kricorian G, Fitzpatrick RE: Full face laser resurfacing: therapy and prophylaxis for actinic keratoses and non-melanoma skin cancer. Lasers Surg Med 2004;34:114-9.

32. Hantash BM, Stewart DB, Cooper ZA, et al: Facial resurfacing for nonmelanoma skin cancer prophylaxis. Arch Dermatol 2006;142:976-82.

33. Nouri K, Chang A, Trent JT, Jiménez GP: Ultrapulse CO2 used for the successful treatment of basal cell carcinomas found in patients with basal cell nevus syndrome. Dermatol Surg 2002;28:287-90.

34. Campolmi P, Brazzini B, Urso C, et al: Superpulsed CO2 laser treatment of basal cell carcinoma with intraoperatory histopathologic and cytologic examination. Dermatol Surg 2002;28:909-11.

35. Humphreys TR, Malhotra R, Scharf MJ, et al: Treatment of superficial basal cell carcinoma and squamous cell carcinoma in situ with a high-energy pulsed carbon dioxide laser. Arch Dermatol 1998;134:1247-52.

36. Iyer S, Bowes L, Kricorian G, Friedli A, Fitzpatrick RE: Treatment of basal cell carcinoma with the pulsed carbon dioxide laser: a retrospective analysis. Dermatol Surg 2004;30:1214-8.

37. Boyce S, Alster TS: CO2 laser treatment of epidermal nevi: long-term success. Dermatol Surg 2002;28:611-4.

38. Michel JL, Has C, Has V: Resurfacing CO2 laser treatment of linear verrucous epidermal nevus. Eur J Dermatol 2001:11:436-9.

39. Touma DJ, Krauss M, Feingold DS, Kaminer MS: Benign familial pemphigus (Hailey-Hailey disease). Treatment with the pulsed carbon dioxide laser. Dermatol Surg 1998;24:1411-4. 
40. Madan V, Ferguson JE, August PJ: Carbon dioxide laser treatment of rhinophyma: a review of 124 patients. Br J Dermatol 2009;161:814-8.

41. Tierney EP, Hanke CW: Treatment of nodules associated with port wine stains with $\mathrm{CO} 2$ laser: case series and review of the literature. J Drugs Dermatol 2009;8:157-61.

42. Minkis K, Geronemus RG, Hale EK: Port wine stain progression: a potential consequence of delayed and inadequate treatment? Lasers Surg Med 2009:41:423-6.

43. Toriyama K, Kamei Y, Kazeto T, et al: Combination of short-pulsed CO2 laser resurfacing and cultured epidermal sheet autografting in the treatment of vitiligo: a preliminary report. Ann Plast Surg 2004;53:178-80.

44. Anbar T, Westerhof W, Abdel-Rahman A, El-Khayyat M, El-Metwally Y: Treatment of periungual vitiligo with erbium-YAG-laser plus 5-flurouracil: a left to right comparative study. J Cosmet Dermatol 2006;5:135-9.

45. Bittencourt RC, Huilgol SC, Seed PT, et al: Treatment of angiofibromas with a scanning carbon dioxide laser: a clinicopathologic study with long-term follow-up. J Am Acad Dermatol 2001;45:731-5.

46. Shin JU, Roh MR, Rah DK, et al: The effect of succinylated atelocollagen and ablative fractional resurfacing laser on striae distensae. J Dermatolog Treat 2011:22:113-21.

47. Oni G, Mahaffey PJ: Treatment of recalcitrant warts with the carbon dioxide laser using an excision technique. J Cosmet Laser Ther 2011:13:231-6.

48. Mitsuishi T, Sasagawa T, Kato T, et al: Combination of carbon dioxide laser therapy and artificial dermis application in plantar warts: human papillomavirus DNA analysis after treatment. Dermatol Surg 2010;36:1401-5.

49. Teikemeier G, Goldberg DJ: Skin resurfacing with the erbium:YAG laser. Dermatol Surg 1997;23:685-7.

50. Perez MI, Bank DE, Silvers D: Skin resurfacing of the face with the Erbium:YAG laser.Dermatol Surg 1998;24:653-8.

51. Khatri KA, Machado A, Magro C, Davenport S: Laser peel: facial rejuvenation with a superficial erbium:YAG laser treatment.J Cutan Laser Ther 2000;2:119-23.

52. Avram DK, Goldman MP: The safety and effectiveness of single-pass erbium:YAG laser in the treatment of mild to moderate photodamage. Dermatol Surg 2004;30:1073-6.

53. Goldman MP, Fitzpatrick RE, Manuskiatti W: Laser resurfacing of the neck with the Erbium: YAG laser. Dermatol Surg 1999;25:164-8.

54. Christian MM: Microresurfacing using the variable-pulse erbium:YAG laser: a comparison of the 0.5- and 4-ms pulse durations. Dermatol Surg 2003;29:605-11.
55. Lodhi A, Huzaira M, Khatri KA: Erbium:YAG laser skin resurfacing: a Pakistani experience. J Cosmet Laser Ther 2003;5:43-9.

56. Kim YJ, Lee HS, Son SW, Kim SN, Kye YC: Analysis of hyperpigmentation and hypopigmentation after Er:YAG laser skin resurfacing. Lasers Surg Med 2005;36:47-51.

57. Tanzi EL, Alster TS: Side effects and complications of variable-pulsed erbium:yttrium-aluminum-garnet laser skin resurfacing: extended experience with 50 patients. Plast Reconstr Surg 2003;111:1524-10.

58. Tanzi EL, Alster TS: Single-pass carbon dioxide versus multiple-pass Er:YAG laser skin resurfacing: a comparison of postoperative wound healing and side-effect rates. Dermatol Surg 2003;29:80-4

59. Khatri KA: Ablation of cutaneous lesions using an erbium:YAG laser. J Cosmet Laser Ther 2003;5:150-3.

60. Baba M, Bal N: Efficacy and safety of the short-pulse erbium:YAG laser in the treatment of acquired melanocytic nevi. Dermatol Surg 2006;32:256-60.

61. Pearson IC, Harland CC: Epidermal naevi treated with pulsed erbium:YAG laser. Clin Exp Dermatol 2004;29:494-6.

62. Ostertag JU, Quaedvlieg PJ, Kerckhoffs FE, et al: Congenital naevi treated with erbium:YAG laser (Derma K) resurfacing in neonates: clinical results and review of the literature. $\mathrm{Br} J$ Dermatol 2006:154:889-95.

63. Kwon SD, Kye YC: Treatment of scars with a pulsed Er:YAG laser. J Cutan Laser Ther 2000;2:27-31.

64. Wollina $U$, Konrad $H$, Karamfilov $\mathrm{T}$ : Treatment of common warts and actinic keratoses by Er:YAG laser. J Cutan Laser Ther 2001;3:63-6.

65. McDaniel DH, Lord J, Ash K, Newman J: Combined CO2/erbium:YAG laser resurfacing of peri-oral rhytides and side-by-side comparison with carbon dioxide laser alone. Dermatol Surg 1999;25:285-93.

66. Trelles MA, Allones I, Luna R: One-pass resurfacing with a combined-mode erbium: YAG/CO2 laser system: a study in 102 patients. $\mathrm{Br} J$ Dermatol 2002;146:473-80

67. Fleming D: Controversies in skin resurfacing: the role of erbium. J Cutan Laser Ther 1999;1:15-21.

68. Khatri KA, Ross V, Grevelink JM, Magro CM, Anderson RR: Comparison of erbium:YAG and carbon dioxide lasers in resurfacing of facial rhytides. Arch Dermatol 1999;135:391-7.

69. Adrian RM: Pulsed carbon dioxide and long pulse 10-ms erbium-YAG laser resurfacing: a comparative clinical and histologic study. J Cutan Laser Ther 1999;1:197-202. 